\title{
Danmarks militære aktivisme fortsætter med eller uden USA
}

\author{
Peter Viggo Jakobsen \\ Lektor, Institut for Strategi, Forsvarsakademiet og Professor (deltid), Center for War Studies, \\ Syddansk Universitet
}

Det er en udpræget misforståelse, at Danmarks militære aktivisme står og falder med USA's position som verdens dominerende magt. Danmark begyndte at bruge sine væbnede styrker aktivistisk uden for landets grænser inden amerikanerne etablerede sig som en global magt efter afslutningen på 2. verdenskrig. Såfremt amerikanerne holder op med at bede Danmark om militære bidrag, vil aktivismen fortsætte i samarbejde med Frankrig, Storbritannien, FN og EU (hvis forsvarsforbeholdet ophæves). Aktivismen har siden starten i 1920 været båret at bred politisk konsensus med Irakkrigen (2003) som eneste undtagelse.

Det har været populært i kølvandet af Irak- og Afghanistankrigene at hævde, at Danmarks voksende anvendelse af det militær instrument siden 1989 først og fremmest har været drevet af ønsket om at komme til kaffe i det Hvide Hus. Det er også dette lighedstegn mellem den udenrigspolitiske aktivisme og opbakning til USA, der ligger til grund for dette temanummer om dansk udenrigspolitisk aktivisme. Udgangspunktet er spørgsmålet, om USA's faldende magt vil rive tæppet væk under Danmarks militære aktivisme (Jacobsen og Wivel intro artikel dette nr; se også Knudsen 2014; Mouritzen 2011; Pedersen 2011, 85).

Danmarks militære aktivisme er forsøgt aflivet adskillige gange (Petersen 2010; Rynning 2006; Wivel 2013, 33-35), men rygterne om dens snarlige død har hver gang vist sig at være stærkt overdrevne. Det er de også denne gang. Argumentet i denne artikel er, at den aktivistiske udenrigspolitik og brugen af det militære instrument vil fortsætte, også hvis USA skulle holde op med at bede
Danmark om militære bidrag. Det skyldes, at Danmarks militære aktivisme altid har været drevet af mere end hensynet til USA. Dansk militær aktivisme er en funktion af internationale rammebetingelser (efterspørgsel/samarbejdsmuligheder og trusler), vilje (indenrigspolitisk konsensus) og Forsvarets kapacitet. Dansk militær aktivisme har siden fødslen været (1) drevet af en stærk cocktail af nationale interesser og værdier, (2) dimensioneret af truslen mod dansk territorium og Forsvarets kapaciteter og (3) kendetegnet af stor indenrigspolitisk konsensus. Eneste undtagelse er Irakkrigen i 2003. Det vil den også være fremover, uanset hvordan amerikansk udenrigs- og sikkerhedspolitik udvikler sig.

Artiklen starter med at definere militære aktivisme og præsentere analysemodellens tre komponenter. Analysemodellen anvendes dernæst $\mathrm{i}$ en analyse af dansk militær aktivisme i mellemkrigstiden, under den kolde krig, i 1990erne, i Fogh Rasmussens regeringstid og sluttelig i den efterfølgende periode 2009-2014. Konklusionen opsummerer analysens hovedpunkter, der danner grundlag for forudsigelsen om, at Danmark vil fortsætte sin militære aktivisme lige så langt øjet rækker.

\section{Aktivisme og dens determinanter}

Det er en udpræget misforståelse, at Danmarks militære aktivisme først starter med murens fald og Sovjetunionens sammenbrud. Men for at kunne vise det, må man først forklare, hvad udenrigspolitisk aktivisme er for en størrelse. Aktivisme er nemlig blevet et plusord, som bruges på så mange måder, at det efterhånden er blevet tømt for mening (Branner 2013, 136-38). Udenrigspolitisk aktivisme forstås her bredt som aktiviteter, der har til formål at påvirke de internationale omgivelser på en måde, som fremmer danske interesser og værdier i situationer, 
hvor den nationale sikkerhed og overlevelse ikke er truet. Militær aktivisme er noget man vælger for at opnå andet og mere end national sikkerhed. Jeg udelukker brugen af militær magt til nationalt selvforsvar for at gøre begrebet så enkelt og klart som muligt. Det dækker derfor kun anvendelse af det militære instrument til internationale aktiviteter, der rækker udover selvforsvar. Bygningen af Københavns befæstning, indtræden i NATO eller suverænitetshåndhævelse er således ikke udtryk for aktivisme. Det er deltagelse i internationale operationer eller træning af andre landes sikkerhedsstyrker derimod, fordi Danmark gennem sådanne aktiviteter yder et aktivt bidrag for at præge sine internationale omgivelser på en måde, som fremmer (inter)national fred og sikkerhed. Selvfølgelig styrker sådanne aktiviteter også den nationale sikkerhed indirekte, hvis de for eksempel øger sandsynligheden for at andre lande vil hjælpe Danmark i en krisesituation. Men det gør en forskel, at militær aktivisme vælges mere af „lyst“ end nød. Aktivisme er langt hen af vejen overskudshandlinger som foretages hvis den nationale sikkerhed er sikret. Danmark var ikke tvunget til at deltage i krigene i Afghanistan, Irak og Libyen. Det ville ikke have forringet Danmarks nationale sikkerhed markant at have undladt at deltage i nogle af disse krige, hvilket mange NATO lande også undlod at gøre. Danmark kunne i stedet have kompenseret $\mathrm{i}$ forhold til sine allierede ved at bidrage til løsningen af andre opgaver.

Aktivismens form og indhold på et givet tidspunkt afhænger af tre faktorer: de internationale rammebetingelser (trusler og international efterspørgsel/samarbejdsmuligheder), vilje og kapacitet. Et højt trusselsniveau vil alt andet lige begrænse Danmarks mulighed for militær aktivisme, fordi det vil binde mange diplomatiske og militære ressourcer til forsvaret af det nationale territorium. Det var tilfældet i hele perioden fra 1864 og frem til 1989, hvor Danmark var nødt til at kalkulere med en risiko for hhv. tysk og sovjetisk aggression i en krise/krigssituation. Bortfaldet af den sovjetiske trussel ved afslutningen af den kolde krig skabte en ny geostrategisk situation, som gjorde det muligt for Danmark at anvende det meste af sin militære kapacitet til aktivistiske formål.

Den internationale efterspørgsel på militære bidrag til aktivistiske formål og de militære samarbejdsmuligheder er også af stor betydning, da et lille lands aktivisme i reglen vil være afhængigt af støtte fra andre. Dansk (militær) aktivisme har altid haft en multilateral karakter og i høj grad været formet af allierede og venners ønsker og opbakning. De nordiske lande og stormagternes ønsker var omdrejningspunktet for dansk militær aktivisme før og under den kolde krig, mens NATO alliancen og dens stormagter får stadig større betydning i den efterfølgende periode.
Viljen til aktivisme er en funktion af indenrigspolitisk enighed. I og med at aktivisme er defineret som internationale aktiviteter, der ikke er direkte relateret til national overlevelse eller forsvar af hjemlandet, er de ikke direkte nødvendige men i højere grad et spørgsmål om lyst. Jo længere væk militær aktivisme bevæger sig fra forsvaret af det nationale territorium, desto mere vokser behovet for at legitimere den. En regerings vilje til at agere aktivistisk afhænger derfor af dens evne til at mobilisere bred politisk og folkelig opbakning. En sådan opbakning er i reglen en nødvendighed, hvis en regering skal risikere sine soldaters liv og lemmer i operationer, hvor den nationale sikkerhed ikke er direkte truet. Ellers løber den en stor risiko for, at vælgerne vil straffe den ved valgurnerne, hvis det går galt. Af samme grund har aktivisme uden bred politisk opbakning typisk kort levetid.

Endelig kræver militær aktivisme militære styrker med den rette træning og udrustning. Her er reaktionstiden og evnen til at indsætte, støtte og beskytte sine styrker uden for eget territorium centrale parametre, da militær aktivisme i reglen foregår på udebane og anmodninger om bidrag kan komme med kort varsel.

\section{Den militære aktivisme starter i mellemkrigstiden}

Anvender vi denne analysemodel på Danmark, starter tilløbet til den militære aktivisme allerede 1920, hvor Danmark opstiller et bidrag til en international militær styrke, der på vegne af Folkeforbundet skal overvåge en folkeafstemning i Vilnius. Soldaterne kommer imidlertid aldrig afsted, da missionen aflyses. Den reelle start på den danske militære aktivisme kommer derfor først i 1937, da Danmark stiller med styrkechefen (oberst C.D.O. Lunn) og et kontingent på 30 mand til den internationale observatørstyrke, som Ikke-Interventionskomiteen på vegne af 26 lande, herunder alle de europæiske stormagter, indsætter på grænsen mellem Spanien og Frankrig i 1937-39 for at inddæmme den spanske borgerkrig (Jakobsen 2009, 12).

Den danske beredvillighed til at støtte Folkeforbundet og Ikke-Interventionskomiteen med soldater er et klart udtryk for militær aktivisme, da disse operationer ikke direkte tjener til at forsvare det danske territorium men i stedet bakker op om internationale bestræbelser på at løse mellemstatslige tvister med fredelige midler og begrænse de negative konsekvenser, som igangværende væbnede konflikter kunne have for stabiliteten i Europa. Den spirende militære aktivisme var led i en bredere udenrigspolitisk aktivisme, hvor Danmark sammen med andre små og mellemstore europæiske lande som Norge, Sverige og Holland indenfor rammerne af Folkeforbundet arbejdede for at fremme etableringen af en international retsorden, hvor mellemstatslige tvister blev afgjort ved forhandlingsbordet og ikke på slagmarken. Folkeforbun- 
det blev oprettet i 1920 for at forhindre en gentagelse af 1. Verdenskrig, og Danmark gjorde en aktiv indsats for at fremme nedrustning, bilateral mægling og etableringen af den Permanente Domstol for mellemfolkelig Retspleje - forløberen for Den Internationale Domstol, der ligger i Haag i dag (Gram-Skjoldager 2012).

Indholdet og formen af den militære aktivisme i mellemkrigsårene var betinget af de internationale rammebetingelser og det nationale syn på brugen af militærmagt. Det var begrænset, hvad stormagterne kunne enes om i mellemkrigstiden, og det blev mindre og mindre i takt med, at Mussolini og Hitler begyndte at føre en stadig mere aggressiv udenrigspolitik i løbet af 1930erne. Den internationale efterspørgsel på militære bidrag var derfor lille og begrænset til observatørstyrker, der ikke skulle udføre offensive operationer. Danmark havde som følge af nedskæringer på forsvarsbudgettet efter afslutningen på 1. Verdenskrig heller ikke særlig megen kapacitet at gøre godt med til aktivistiske formål, og tiltroen til at det kunne nytte at bruge militær magt til offensive formål kunne ligge på et meget lille sted. Det samme gjaldt troen på, at Danmark på egen hånd kunne opstille et forsvar, der ville kunne afskrække Tyskland fra at angribe Danmark (Lidegaard 2003). Derfor var der blandt danske beslutningstagere enighed om ikke at gå videre end at bidrage til observatør missioner. Det primære fokus i dansk udenrigspolitik var at teste, hvor langt man kunne nå med hensyn til at skabe en ny international retsorden med Folkeforbundet som omdrejningspunkt uden at blive involveret i fremtidige stormagtskonflikter. Det var således en forudsætning for Danmarks indtræden i Folkeforbundet, at det var foreneligt med den neutralitetspolitik, der havde holdt landet ude af 1 . Verdenskrig, og at medlemskabet ikke forpligtede Danmark til at gå i krig for at undsætte lande, der blev udsat for militær aggression. Danmark søgte ligeledes også at undgå en forpligtigelse til at indføre økonomiske sanktioner mod krigsførende lande (Gram-Skjoldager 2012).

Den gængse opfattelse af mellemkrigstidens og udenrigsminister P. Munchs udenrigspolitik som en ren 'liggedød politik' er med andre ord ikke helt retvisende. Den havde elementer af (militær) aktivisme, som dog aftog i takt med den voksende trussel fra Hitler-Tyskland reducerede rummet for den.

\section{Den militære aktivisme får vokseværk under den kolde krig}

Danmark videreførte sin politik fra Folkeforbundet i De Forende Nationer (FN), hvilket ikke er videre overraskende i og med, at de to organisationer havde samme hovedformål: at forhindre en ny verdenskrig og arbejde for etableringen af en international retsorden baseret på fredelig konfliktløsning. Den store forskel på de to perioder set med udenrigs- og sikkerhedspolitiske øjne er beslutningen om at opgive neutralitetspolitikken til fordel for medlemskabet af NATO (North Atlantic Treaty Organization) i 1949. Den udsprang af de ændrede internationale rammebetingelser: den voksende trussel fra Sovjetunionen og den nye mulighed for at blive medlem af en militær alliance, som kunne yde Danmark troværdig militær beskyttelse mod den sovjetiske trussel. At man udnyttede denne mulighed skyldes bred politisk enighed om, at neutraliteten havde spillet fallit 9. april 1940 og heller ikke ville kunne garantere Danmarks sikkerhed fremover.

NATO medlemskabet fik imidlertid ikke nogen betydning for Danmarks udenrigspolitiske aktivisme. Indenfor rammerne af FN fortsatte Danmark sit samarbejde med andre små og mellemstore stater med det formål at fremme etableringen af en international retsorden og bidrage til international afspænding og nedrustning. Det tætte samarbejde med Norge og Sverige fortsatte og Finland kom med, da det blev medlem af FN i 1955. Ideen om, at småstater nok måtte indrette sig efter de gældende internationale magtforhold men også havde en moralsk forpligtigelse til aktivt at bidrage til at skabe en mere fredelig verden, levede videre i FN politikken.

Som det var tilfældet i mellemkrigstiden havde den nationale overlevelse første prioritet. NATO medlemskabet fik ikke Danmark til at optræde udfordrende i forhold til Sovjetunionen. Som det var tilfældet i mellemkrigstiden, holdt Danmark en lav profil på områder, hvor stormagterne var uenige. Frygten for at komme i klemme mellem Sovjetunionen og USA fik Danmark til at holde lav profil i FN i 1950erne. Danmark smøg sig udenom, da muligheden for at indtræde i Sikkerhedsrådet opstod i 1950, og hovedambitionen var at holde lav profil og undgå at komme i klemme, da Danmark tog sin første tørn i Sikkerhedsrådet i 1953-54.

På det militære område var Danmark mindre tilbageholdende. Her var Danmark, som det var tilfældet under Folkeforbundet, fra første færd parat til at bidrage til militære operationer for at bevare freden og forhindre mindre konflikter $i$ at udvikle sig til konfrontationer imellem stormagterne. Danmark bidrog med soldater, da de første FN operationer løb af stablen i Mellemøsten og Kashmir i 1948-49, og Danmark bidrog sammen med Norge med en bataljon, da FN for første gang i forbindelse med Suez krisen i 1956 indsatte en letbevæbnet militær styrke for at overvåge en våbenhvile. Danmark bidrog til alle FN's missioner i perioden 1948-89, bortset fra tre og havde kontinuerligt soldater udsendt gennem hele perioden. I alt bidrog Danmark med 34,100 soldater til FN's operationer under den kolde krig. Det svarer til godt $7 \%$ af alle ind- 
satte FN soldater, hvilket gjorde Danmark til en af de største troppebidragydere målt i forhold til befolkningsantal.

Disse operationer afspejlede de internationale rammebetingelser. De blev indsat i situationer, hvor både Sovjetunionen og USA så en fælles interesse $\mathrm{i}$ at forhindre lokale konflikter $i$ at eskalere til en direkte konfrontation mellem dem selv, og det betød, at Danmark kunne bidrage uden at træde dem over tæerne og på den måde bidrage til international afspænding. Danmark høstede sammen med de øvrige nordiske lande stor ros for sin aktivisme på området, og det gav de fire nordiske lande en meget større gennemslagskraft i FN, end deres størrelse tilsagde.

Efterhånden som FN operationerne blev institutionaliseret, blev Danmark nærmest per automatik anmodet om militære bidrag, når en ny FN operation var på tegnebrættet. Det skyldes dels, at Danmark som regel opfyldte FNs fire krav til deltagerlandene: (1) De måtte ikke være permanente medlemmer af Sikkerhedsrådet, (2) de måtte ikke komme fra den region, hvor konflikten foregik eller have særlige interesser i den, (3) de skulle accepteres af værtslandet, (4) og de skulle være i stand til at stille med soldater med kort varsel. Men den primære årsag var, at Danmark havde deltaget fra starten og bidraget til at udvikle principperne for FNs fredsbevarende arbejde i tæt samarbejde med Norge og Sverige. Danmark var også blandt de første til at øremærke soldater til FN-tjeneste i 1964.

Den danske opbakning skyldtes en indenrigspolitisk konsensus om, at det både var i dansk interesse og i overensstemmelse med danske værdier at bidrage til international afspænding og nedrustning. Danske politikere betragtede $\mathrm{FN}$-operationerne som en måde at fremme etableringen af en international retsorden kendetegnet ved respekt for folkeretten, fredelig konfliktløsning og et fravær af stormagtsmagtmisbrug, og operationerne nød bred parlamentarisk opbakning, så længe de ikke gik ud over NATO medlemskabet og forsvaret af Danmark, krævede brug af magtanvendelse udover selvforsvar, eller bragte Danmark på kollisionskurs med nogen af stormagterne.

Anmodninger om troppebidrag, som ikke overholdt disse betingelser, blev afvist. Det skete i forbindelse med Koreakrigen, som en multinational styrke anført af USA udkæmpede på mandat fra FN, fordi Sovjetunionen havde boykottet det møde i Sikkerhedsrådet, hvor beslutningen var blevet taget. USA og FN måtte i denne operation tage til takke med et hospitalsskib. Et tilsagn om kampsoldater ville have bragt Danmark på kollisionskurs med Sovjetunionen og Kina, hvorfor den danske regering afslog anmodningerne med den begrundelse, at det ville svække forsvaret af Danmark.

Forsvaret af Danmark havde første prioritet under hele den kolde krig, og entusiasmen for FN operationerne hænger derfor også sammen med, at den ikke svæk- kede det hjemlige beredskab. Langt hovedparten af de danske FN soldater bestod af frivillige, der havde aftjent deres værnepligt med tilfredsstillende resultat, og som ikke længere indgik i forsvaret. Personelbelastningen for det danske territorialforsvar var derfor minimal, og det samme gjaldt økonomien, da udgifterne til FN-styrken blev afholdt uden for forsvarsbudgettet og delvist blev dækket af refusioner fra FN. Da de danske FN styrker stort set ikke led tab, var der heller ikke nogen større menneskelige omkostninger forbundet med deltagelsen. FN operationernes popularitet er derfor ikke svær at forstå, da de skabte enighed og stolthed hjemme og prestige og indflydelse ude for en meget begrænset indsats og risiko (Jakobsen 2009, 14-27).

\section{Murens fald sætter turbo på den militære aktivisme}

De internationale begrænsninger, der havde kendetegnet den militære aktivisme under den kolde krig, forsvandt med murens fald. Det forbedrede samarbejdsklima i Sikkerhedsrådet banede vej for langt mere ambitiøse operationer, som gjorde det muligt at føre krig med Rådets opbakning, noget som ville have været utænkeligt under den kolde krig. Den første Golfkrig i 1991 indvarslede den nye tid ved at godkende et amerikansk-ledet angreb på Irak med det formål at smide de irakiske besættelsesstyrker ud af Kuwait. Golfkrigen blev efterfulgt af et stigende antal militære operationer, hvor FN-styrker eller regionale organisationer (fx NATO) og koalitioner af villige med mandat fra $\mathrm{FN}$ brugte våbenmagt udover selvforsvar for at håndhæve FN's resolutioner (Jakobsen 2009, 46-57).

Borgerkrigen i Bosnien blev katalysator for den udvikling, og den skabte et pres på de europæiske lande til at bidrage med soldater til operationer under krigslignende forhold udført af først FN og siden NATO. Denne internationale efterspørgsel opstod samtidig med, at den militære trussel mod NATO's og Danmarks territorium forsvandt. For Danmarks vedkommende skabte det en ny situation med en uset grad af sikkerhed uden en truende stormagt i nabolaget. Danmarks geostrategiske position blev yderligere forbedret $\mathrm{i}$ takt med, at Polen og de baltiske lande blev indlemmet i EU og NATO og bidrog til at skabe en buffer mellem Danmark og Rusland.

Udviklingen gav Danmark maksimalt handlerum i forhold til føre en aktivistisk udenrigspolitik med såvel civile som militære instrumenter, og det udnyttede danske beslutningstagere hurtigt. Allerede i 1994 er Danmark den største bidragyder til operationerne på Balkan målt per indbygger (Drachmann 1994). Danmark har på det tidspunkt soldater i Kroatien, Makedonien og Bosnien og 
krigsskibe i Adriaterhavet, som deltager i den maritime embargo af Serbien og Montenegro.

Målt på antallet af indsatte soldater mere end fordobler Danmark sin aktivisme i løbet af 1990erne. Hvor Danmark i gennemsnit havde 812 soldater indsat om året $\mathrm{i}$ internationale operationer under den kolde krig, er gennemsnittet for 1990erne 1.940, og rekorden bliver sat i 1999, hvor 2.323 soldater i en periode er indsat samtidigt. I løbet af 1990erne sker der desuden det, at alle tre værn samt specialstyrkerne bliver involveret i internationale operationer. Under den kolde krig var det kun hæren, som bidrog (Jakobsen 2009, 84-85).

Den indenrigspolitiske konsensus og folkelige opbakning, der er forudsætningen for den øgede militære aktivisme, skabes gradvist og i forlængelse af en politisk ambition om at udnytte den nye verdensorden til at føre en mere aktivistisk udenrigspolitik. Det kommer i første omgang til udtryk i forhold til et succesrigt politisk engagement i forhold til Baltikum. Denne aktivisme bliver hurtigt udvidet til det militære område, hvor det bliver præsenteret som en naturlig forsættelse af engagementet i FN operationerne under den kolde krig. Udenrigsminister Uffe Ellemann-Jensen (Venstre, 1982-1993) og forsvarsminister Hans Hækkerup (Socialdemokratiet, 19932000) går forrest i denne udvikling, og de ser det begge som en måde at reparere det ramponerede image i NATO og i forhold til USA, som Danmark havde fået som konsekvens af modstanden mod NATOs atompolitik (fodnotepolitikken) i 1980erne (Jakobsen 2009, 86-90, 92-94).

Udover troppebidrag til internationale operationer, resulterede den militære aktivisme også i et omfattede uddannelsessamarbejde med de baltiske lande, Polen og Rusland, etableringen af Det Baltiske Forsvarsakademi (Baltic Defence College) og en baltisk bataljon (BALTBAT) samt oprettelsen af en multinational styrke øremærket til hurtige indsættelse på FN operationer med hovedkvarter på Høvelte Kaserne (SHIRBRIG). Den militære aktivisme får for alvor momentum, da den danske indsættelse af kampvogne i Bosnien giver Danmark status som foregangsland og rollemodel i både FN, NATO og USA. Det sker som følge af en træfning 29. april 1994, hvor de danske kampvogne falder i et serbisk baghold og succesfuldt besvarer ilden ved at affyre 72 granater og nedkæmper alle de angribende styrker. På hjemmefronten bliver Operation Bøllebank en kilde til national stolthed og forstærker danske beslutningstagere i troen på, at militær aktivisme er en god ide. Det er en tro, der får yderligere næring op gennem 1990erne i takt med, at den fortsatte aktivisme bringer Danmark ind i inderkredsen i NATO, i FN hvor Hans Hækkerup som følge af SHIRBRIG initiativet får et nært forhold til Kofi
Annan, og i USA, som kvitterer med Præsident Clintons besøg i København i 1997.

Konsekvensen af forsvarets voksende synlighed i udenrigs- og sikkerhedspolitikken bliver et mere positivt syn på militær magtanvendelse. Det bliver legitimt og naturligt at bruge militær magt offensivt for at beskytte civile mod systematiske overgreb. At danskernes selvforståelse har ændret sig bliver tydeligt for enhver i forbindelse med Kosovokrigen i 1999, der er mere populær i Danmark end noget andet sted, og hvor det vækker glæde og stolthed, at danske F-16 fly også kaster bomber mod serbiske mål (Jakobsen 2000).

For at kunne imødekomme den konstant voksende politiske efterspørgsel på internationale bidrag gennemgår det danske forsvar en løbende transformationsproces op gennem 1990erne hvor alle forsvarets enheder og materiel gradvist omstilles til at kunne operere langt fra Danmark i længere tid. Det var forsvaret slet ikke gearet til, da muren faldt, og det er en transformationsproces der fortsætter op gennem 00erne og stadig pågår i dag (Jakobsen 2009; Jakobsen og Rynning under udgivelse).

\section{Fogh Rasmussen perioden: mere kontinuitet end sporskifte}

Terrorangrebet 11. september 2001 ændrede de internationale rammebetingelser markant, fordi USA erklærede krig mod terror og slog ind på en mere aggressiv udenrigspolitisk kurs. På det militære område betød det, at USA nu bad om bidrag til kampoperationer, og det stillede højere krav til de allieredes militære kapaciteter og vilje til at bruge magt. Hvor 1990erne primært handlede om at true og bruge magt til at tvinge parter til at respektere FNs resolutioner og respektere våbenhviler og fredsaftaler, så kommer 00erne til at handle om at besejre fjender og påtvinge dem demokrati med magt.

De nye internationale krav satte den indenrigspolitiske konsensus og Forsvarets kapaciteter under pres, fordi Danmark i udgangspunktet ikke var gearet til sådanne operationer. Da en dansk Hercules besætning med kort varsel beordres til at flyve danske specialstyrker ind $\mathrm{i}$ krigszonen i Afghanistan i 2001 var aftalerne med USA ikke på plads, og en ordre om at se stort på de normale sikkerhedsregler udløser protester fra piloterne (Halskov og Svendsen 2012, 100-107). Socialdemokraterne og Det Radikale Venstre havde svært ved at acceptere indsættelsen af danske specialstyrker i Afghanistan med det formål at nedkæmpe Taleban-regimet, og den normale politiske konsensus bryder sammen, da Fogh Rasmussen regeringen med et snævert flertal på 11 stemmer sender danske soldater i krig i Irak i 2003 uden FN mandat og i en situation, hvor der er stærk modstand i både EU og NATO. 
Beslutningen om at gå i krig i Irak ses af de fleste forskere og analytikere som et markant sporskifte i dansk udenrigs- og sikkerhedspolitik (Gram-Skjoldager og Pedersen 2015). Denne tolkning bygger på to forhold. Den første er, at en dansk regering aldrig tidligere havde sendt danske soldater på en international mission uden bred opbakning i Folketinget. Det andet er, at landoperationerne i Irak og Afghanistan blev de hårdeste siden 1864. Danmark mistede flere soldater i Afghanistan (43) end i alle andre internationale operationer tilsammen siden den 2. Verdenskrig (Jakobsen og Ringsmose 2014).

Problemet med sporskiftetesen er, at den stirrer sig blind på Irak beslutningen og overser de mange fællestræk, som Fogh Rasmussen perioden har med 1990erne. Fogh Rasmussen regeringen fremlægger $i$ alt 20 beslutningsforslag i Folketinget om udsendelse af danske militærbidrag. ${ }^{1} 18$ af disse forslag får bred opbakning i Folketinget, og kun Irak beslutningen er i strid med FN pagten og folkeretten. Det er derfor misvisende, at se Fogh Rasmussen regeringerne (2001-2009) som meget mindre FN loyale end Nyrup Rasmussen regeringerne (1993-2001), der (med bred opbakning fra Folketinget) tilbød at bidrage militært til to amerikansk-ledede angreb uden FN mandat: det amerikansk-britiske luftangreb på Irak i 1998 og NATOs Kosovokrig året efter. Dette tætte danske samarbejde med NATO/USA i 1990erne gør det også svært at argumentere for, at Fogh Rasmussen er markant mere pro-amerikansk end Nyrup regeringerne. Skiftet fra FN til NATO/USA-ledede missioner sker under Nyrup Rasmussen perioden, og Fogh Rasmussen var heller ikke den første til at sende danske soldater i krig mod et andet land. Det gjorde Nyrup Rasmussen med beslutningen om lade danske F-16 udføre offensive operationer mod Serbien under Kosovokrigen.

Ser vi på formålet med militær aktivismen under Fogh Rasmussen, er det kun de to beslutninger om at gå i krig for at vælte regimerne i Afghanistan og Irak, der skiller sig ud. De øvrige 18 beslutninger har samme mål som operationerne op gennem 1990erne. Periodens to store operationer, indsættelsen af danske hærstyrker i Afghanistan og Irak efter regimernes fald, har samme mål som NATO operationerne på Balkan: at stabilisere de to lande så man kunne komme i gang med at genopbygge dem. Ingen forventede at møde så megen modstand nogen af de to steder, at soldaterne ville blive tvunget til at udføre oprørsbekæmpelse under krigslignende forhold i årevis.

Der er også kontinuitet, der springer i øjnene, hvis man sammenligner den militære aktivismes omfang før og under Fogh Rasmussen. Fra 2002 til 2009 udsendte Danmark 16.813 soldater, hvilket svarer til et årligt gennemsnit på 2.102 (Jakobsen og Rynning under udgivelse). Det er ikke markant større end 1990ernes gennemsnit på 1.940. Udviklingen på forsvarsbudgettet vidner heller ikke om større krigeriskhed. Den faldende tendens fra 1990erne fortsatte: fra 1.6\% af BNP i 2001 til $1.4 \%$ i 2009. Der er dog den forskel, at forsvaret får problemer med at opfylde de politiske krav om større internationale bidrag. Til trods for en fortsat omstilling, der indebærer en total afvikling af mobiliseringsforsvaret i forbindelse med forsvarsforliget i 2004, bliver Forsvaret aldrig i stand til kontinuerligt at holde 2000 soldater ude i internationale operationer, således som Fogh Rasmussen regeringen $ø$ nsker. Forsvaret kan heller ikke afholde udgifterne til operationen i Afghanistan indenfor de afsatte budgetter.

Endelig er det misvisende at betragte Fogh Rasmussen regeringens beslutning om at bidrage med specialstyrker til krigen mod Taleban regimet i starten af 2002 som en markant afvigelse fra den hidtidige praksis (Halskov og Svendsen 2012, 86, 92). Regeringen havde ikke militær kapacitet til at støtte den amerikanske krigsindsats med andet end de kampfly, transportfly og specialstyrker, den foreslog at udsende. Alternativet var at lade være og udelukkende støtte FN operationen i Afghanistan i stedet således som Socialdemokraterne og det Radikale Venstre foretrak. Australien, Canada, Frankrig, New Zealand, Norge, Storbritannien og Tyskland bidrog imidlertid ligeledes med specialstyrker, hvorfor regeringen lå på linje med en lang række allierede, som Danmark normalt samarbejder med. Med sin beslutning valgte Fogh Rasmussen at fortsætte det tætte samarbejde med USA, som var blevet etableret i 1990erne under Nyrup Rasmussen.

Kapacitetsmæssige overvejelser spillede også en væsentlig rolle i de skæbnesvangre beslutninger om at operere under britisk kommando i Helmand provinsen i 2006 og påtage sig ansvaret for området med den grønne zone, hvor Danmark mistede størstedelen af sine soldater. Alternativer, som kunne have givet Danmark mindre farlige områder og opgaver blev forkastet, fordi det ville blive for dyrt at støtte soldaterne. De operative valg i Afghanistan afspejlede således, at Forsvaret er nødt til at integrere sine enheder stadig tættere med særligt udvalgte allierede, fordi det ikke længere har kapacitet til at løse ret mange opgaver på egen hånd (Jakobsen og Thruelsen 2011).

Opsummerende er der meget større grad af kontinuitet i Fogh Rasmussen periodens militære aktivisme, end den gængse sporskiftetolkning lægger op til. Denne konklusion understøttes af udviklingen i den efterfølgende periode, hvor den militære aktivisme under Løkke Rasmussen 2009-11) og Thorning regeringerne (2011-2015) fortsætter uden nævneværdige ændringer.

\section{Fra Fogh Rasmussen til Thorning}

Erfaringerne fra Irak og Afghanistan ændrede karakteren af den internationale efterspørgsel på militære bidrag 
i denne periode. Den vestlige appetit på nye langvarige landkrige svandt kraftigt ind, og den amerikanske forsvarsminister Gates formulerede prægnant læren fra de to krige med bemærkningen om, at 'enhver fremtidig forsvarsminister, der råder præsidenten til at sende store mængder landtropper ind i Asien, Mellemøsten eller Afrika, burde få sit hoved undersøgt' (Shanker 2011). I stedet satsede USA på den kombination af luftstyrker, specialstyrker og uddannelse af lokale landstyrker, der kendetegnede den sidste fase af operationen i Afghanistan og krigen i Libyen i 2011.

Den nye tilgang kan aflæses direkte i periodens danske militære aktivisme. Antallet af kampsoldater fra hæren faldt i takt med, at USA og NATO afviklede kampoperationen i Afghanistan, mens det gik den modsatte vej med udsendelsen af træningsbidrag (Afghanistan, Irak), kampfly (Baltikum, Island, Libyen og Irak), transportfly (Den Centralafrikanske republik, Irak, Libyen, Mali og Syrien) og helikoptere (Aden, Afghanistan) og flåde + specialstyrker (Aden og Syrien). Skiftet fra hær- til flyog flådeoperationer ses også af, at antallet af udsendte soldater (7.612) gav et årligt gennemsnit på 1.522 for 2010-2014 (Forsvarsministeriets Personalestyrelse, 2015), hvilket er det laveste siden starten af 1990erne, da hæren blev sendt til Balkan.

Bortset fra det kørte den militære aktivisme videre i det kendte spor. Den internationale efterspørgsel på militære bidrag blev ikke mindre, og det gjorde den danske vilje til at imødekomme den heller ikke. Der var ingen krigstræthed at spore hos hverken politikere eller befolkning, da NATO med mandat fra FN i starten af 2011 med kort varsel indledte en luftkrig over Libyen. Alle Folketingets partier og $80 \%$ af befolkningen bakkede op om indsættelsen af kampfly, og det blev endnu engang en kilde til stolthed, at de danske piloter var med i forreste linje og kastede 923 (11\%) af de bomber, der blev brugt $\mathrm{i}$ løbet af missionen (Jakobsen og Møller 2012, 114).

Regeringsskiftet i 2011 under Libyen krigen påvirkede ikke den militær aktivistiske kurs. Den nye socialdemokratisk-ledede Thorning regering sagde med bred opbakning fra Folketinget ja til henvendelser om militære bidrag fra FN, NATO, USA og Frankrig. Den indsatte kampfly i krigen mod Islamisk Stat i 2014 og var også klar til at støtte et amerikansk angreb på Syrien i augustseptember 2013 som straf for dets brug af kemiske våben. Staffeaktionen havde kun opbakning fra Frankrig og Storbritannien og kunne kun udføres uden FN mandat. Det satte støtten fra regeringen og et bredt flertal i Folketinget i relief (Ritzau 2013), at den britiske regering blev nedstemt i parlamentet, da den bad om mandat til at deltage $\mathrm{i}$ angrebet, fordi situationen efter flertallets mening mindede for meget om optakten til Irakkrigen i 2003.
Staffeaktionen blev dog aldrig til noget, da den amerikanske trussel om luftangreb fik det syriske regime til at udlevere de kemiske våben til destruktion. Det banede vej for en FN operation (OPCW-UN Joint Mission), som Danmark ledte flådedelen af.

\section{Konklusion}

Denne historiske analyse af Danmarks militære aktivisme viser, at den har rødder helt tilbage til 1920, da en dansk regering for første gang stiller en militærstyrke til rådighed for en international militær operation med det formål at bidrage til fredelig konfliktløsning. Aktivismen har fra starten været båret af en kortsigtet sikkerhedspolitisk interesse $\mathrm{i}$ at mindske det internationale konfliktniveau for at undgå at blive inddraget $i$ endnu en stormagtskrig og en mere idealistisk langsigtet ambition om at skabe et internationalt retssamfund, som yder småstater bedre beskyttelse mod stormagterne. Denne tankegang fik danske regeringer til at støtte både Folkeforbundet og FN i det omfang, som de skiftende internationale rammebetingelser og hensynet til den nationale sikkerhed tillod det. Frem til 1989 var den militære aktivisme betinget af den militære trussel fra Tyskland og Sovjetunionen, hvilket fik danske beslutningstagere til at afholde sig fra militære operationer, der indebar brug af våbenmagt udover selvforsvar, og som ikke havde alle stormagternes opbakning. Da truslen i nærområdet faldt bort efter 1989, og FN, NATO og USA begyndte at efterspørge bidrag til hårdere missioner, skaber den succesrige indsættelse af kampvogne fundamentet for et mere positivt syn på offensiv militær magtanvendelse, der muliggjorde den efterfølgende krigsdeltagelse i Irak og Afghanistan, Libyen og Irak. Kapaciteten til at deltage i kampoperationer langt fra Danmark tilvejebringes gennem en gennemgribende transformationsproces, som på mindre end tyve år erstatter den kolde krigs territorialforsvar med en mindre ekspeditionsstyrke, der kan indsættes globalt med relativt kort varsel.

Set i det lange tidsperspektiv har Danmarks militære aktivisme været båret af en usædvanlig grad af kontinuitet og indenrigspolitisk enighed. Det store flertal af beslutningstagere har delt ambitionen om at beskytte Danmark og samtidig bidrage til at skabe en mere fredelig, regelstyret og retfærdig verden. Ambitionsniveauet har været højt siden den 2. Verdenskrig, hvor Danmark konstant har været blandt de største bidragydere per indbygger til de militære operationer danske soldater har deltaget i. Det gælder FNs fredsbevarende operationer under den kolde krig, indsatserne på Balkan i 1990erne og indsatsen i Afghanistan i 00erne og senest i Libyen i 2011, hvor danske F-16 fly kastede relativt flest bomber. Karakteren af den danske aktivisme har været først og fremmest været bestemt af den internationale efterspørgsel. Danmark 
bidrog med fredsbevarende styrker i 1920-89, bidrog til at gennemtvinge respekt for våbenhvilker og fredsaftaler med magt i 1990erne og bidrog til oprørsbekæmpelse og krigsindsatser i 00erne. Nu hvor efterspørgslen i stigende grad retter sig mod træningsenheder, stabsbidrag, fly-, flåde- og specialstyrker, er Danmark begyndt at levere det.

Det eneste brud på denne kontinuitet er beslutningen om at deltage i angrebet på Irak i 2003 på grundlag af et snævert flertal i Folketinget samt forlængelsen af den landmilitære tilstedeværelse i Irak i 2006. Men bortset fra den er Fogh Rasmussens regeringstid kendetegnet af lige så stor indenrigspolitisk konsensus og respekt for FN, som det var tilfældet i 1990erne. Hans regering fremstår heller ikke som markant mere pro-amerikansk, end den regering han afløste eller dem, som fulgte efter. Den danske militære aktivisme er sket i tæt samarbejde med USA, siden NATO afløste FN i Bosnien i 1995. Danske regeringer har både før og efter Fogh Rasmussen været rede til at bidrage til kontroversielle amerikansk-ledede militære operationer uden FN mandat.

Kaster vi til slut et blik på fremtiden, peger kompasnålen på fortsat militær aktivisme. Krigen i Ukraine og den voksende militære spænding i Østersøregionen ændrer ikke afgørende på Danmarks sikkerhedspolitiske situation. Rusland er i dag så svagt både økonomisk og militært i forhold til EU og NATO, at det ikke udgør en direkte militær trussel mod NATO og Danmark. Det ses også af, at Danmarks hovedallierede, Frankrig, Storbritannien og USA fortsat opfordrer deres allierede i NATO til fortsætte omstillingen fra territorialforsvar til indsættelsesforsvar og gøre det samme, som Danmark allerede har gjort. USA bruger truslen fra Rusland som pressionsmiddel til at få de europæiske NATO lande til at bruge flere penge på forsvaret men USA ønsker ikke pengene anvendt på at modernisere europæernes invasionsforsvar. De skal i stedet bruges på at købe de kapaciteter, som europæerne mangler for at kunne bidrage effektivt til konflikthåndtering udenfor Europe, dvs. lufttanknings- og løftekapacitet og elektronisk overvågning, efterretningsindhentning og kommunikation (droner, fly, satellitter). Den primære bekymring stormagterne udtrykker i forhold til Danmark er, at de væbnede styrker bliver for små til at kunne yde andet end symbolske bidrag i kortere perioder.
Der er ingen udsigt til at den internationale efterspørgsel på danske militære bidrag vil falde. Eksistensen af 30-50 skrøbelige stater kendetegnet ved svage statsstrukturer, svag intern sammenhængskraft og stor ulighed skaber et konstant behov for militær konflikthåndtering så langt øjet rækker. Det samme gør den igangværende destabilisering af Mellemøsten og Nordafrika. Hertil kommer, at der er stadig færre lande, som har viljen og kapaciteten til at bidrage til militære operationer i den hårde ende af skalaen. Ingen af de europæiske lande har længere kapacitet til at kunne udføre større militære operationer $(+5.000)$ over en længere periode uden for eget nærområde. Det er derfor, at Frankrig og Storbritannien i de senere år har intensiveret deres militære samarbejde med Danmark i forventning om, at de kan trække på dansk assistance, når behovet opstår. FN presser også på for at få flere bidrag for Danmark, så selv hvis USA skulle holde op med at bede om assistance, vil der være mere end rigeligt at se til. Internt i Danmark er der ingen tegn på at politikerne har tænkt sig at skrue ned for den militære aktivisme. Da der er bred opbakning til et fortsat militært engagement på tværs af partierne i Folketinget bliver den primære begrænsning i overskuelig fremtid Forsvarets stadig mindre militære kapacitet. Politikernes vilje til militær aktivisme er væsentligt større end Forsvarets internationale kapacitet.

Det er den brede politiske konsensus om, at militær aktivisme er en god ide, der adskiller Danmark fra andre lande. Den har gjort Danmark mindre sårbar overfor tab og kritikken om, at krigene i Afghanistan, Irak og Libyen har gjort mere skade end gavn. Det har det politiske flertal bag disse indsatser konsekvent afvist med begrundelsen om, at Danmark har gjort sin pligt, og at de danske soldater har udført et godt og professionelt stykke arbejde - hvilket ingen benægter. At målene om demokrati og stabilitet ikke er nået, er beklageligt. Men det er i politikernes optik ikke Danmarks skyld, fordi vi er for små til at kunne gøre en afgørende forskel på krigenes gang.

Tak til Tonny Brems Knudsen for nyttige og konstruktive kommentarer, som forbedrede kvaliteten af artiklen. 


\section{Litteraturliste}

Branner H 2013, 'Denmark between Venus and Mars: How Great a Change in Danish Foreign Policy?', i N. Hvidt og H. Mouritzen (red.), Danish Foreign Policy Yearbook 2013, Danish Institute for International Affairs, Copenhagen, pp. 134-166.

Drachmann, H 1994, ‘Ønske om danske fly til Bosnien’, Politiken, 11. september.

Forsvarsministeriets Personalestyrelse 2014, Udsendte, http://forpers. $\mathrm{dk} / \mathrm{hr} /$ Pages/Udsendte.aspx (25 april).

Gram-Skjoldager, K 2012, Fred og folkeret: dansk internationalistisk udenrigspolitik 1899-1939, Museum Tusculanums Forlag, København.

Gram-Skjoldager, K og Pedersen SB 2015, 'International aktivisme i dansk udenrigspolitik 2001-2009. En tværfaglig forskningsstatus', Historisk Tidsskrift, Bind 119, Hæfte 2.

Jacobsen SG og Wivel A, 2015, „Introduktion“, Politik nr. 4, s. 3-4.

Jakobsen, PV 2000, 'Denmark at War: Turning Point or Business as Usual', i B Heurlin og H Mouritzen (red.), Danish Foreign Policy Yearbook 2000, Danish Institute for International Affairs, Copenhagen, pp. 61-85.

Jakobsen, PV 2000, 'Fra ferie til flagskib: forsvaret og de internationale operationer', Forsvarsakademiet Research Paper, Forsvarets Trykkeri, Korsør.

Jakobsen, PV og Møller KJ 2012, 'Good News: Libya and the Danish Way of War', i N. Hvidt og H. Mouritzen (red.), Danish Foreign Policy Yearbook 2012, Danish Institute for International Affairs, Copenhagen, pp. 106-30.

Jakobsen, PV og Thruelsen, PD 2011, 'Clear, Hold, Train: Denmark's Military Operations in Helmand 2006-2010', i N Hvidt og H Mouritzen (red), Danish Foreign Policy Yearbook 2011, Danish Institute for International Studies, Copenhagen, pp. 78-105.
Jakobsen, PV og Rynning, S under udgivelse, 'Denmark: Happy to Fight, Will Travel', i A Dorman (red.) War and the State.

Jakobsen, PV og Ringsmose J 2014, 'In Denmark, Afghanistan is worth dying for: How public support for the war was maintained in the face of mounting casualties and elusive success', Cooperation and Conflict. vol. 50, no. 2, pp. 211-227.

Knudsen, TB 2014, 'Danish Contributions in Syria and Mali: Active Internationalism in a Changing World Order', i N Hvidt og $\mathrm{H}$ Mouritzen (red.), Danish Foreign Policy Yearbook 2014, Danish Institute for International Studies, Copenhagen, pp. 76-108.

Lidegaard B 2003, Overleveren 1914-1945. Dansk Udenrigspolitisk Historie, bind 4, Gyldendal Leksikon, København.

Mouritzen, H 2011, 'Danmarks nye råderum - efter Libyen', Politiken, 13. maj.

Pedersen, RB 2011, 'Dansk udenrigspolitisk aktivisme i nyt farvand', Udenrigs, vol. 66, no. 1, pp. 81-87.

Petersen, R 2010, 'Aktivistisk udenrigspolitik: Storhed og fald', Politiken, 6. maj.

Ritzau 2013, 'Enighed om dansk opbakning', Information, 30. august. Rynning, S 2006, 'Den ufuldendte strategiske aktør: Danmark og sikkerhedspolitikken siden 2001. Militert tidsskrift, vol. 135, no. 2, pp. 186-95.

Shanker, T 2011, 'Warning Against Wars Like Iraq and Afghanistan', The New York Times, 25. februar.

Wivel, A 2013, 'Danmarks militære aktivisme,' i KS Søby (red.) Danmark $i$ krig: Demokrati, politik og strategi $i$ den militere aktivisme, Djøf Forlag, København, pp. 27-51.

\section{Noter}

1. For en oversigt se: http://www.fred.dk/artikler/fredvalg/ikrig.htm (25. april 2015) 